\title{
Entrepreneurial intentions among students of sultan Qaboos university
}

\section{Salim Saleem Al Ghanboosi}

Associate Professor, Dept. of Foundations, and Educational Administration, Sultan Qaboos

University, Sultanate of Oman

ghnbousi@squ.edu.om

\section{Aieman Ahmad Al-Omari}

Professor, Dept. of Foundations, and Educational Administration, Sultan Qaboos University,

Sultanate of Oman

a.alomari@squ.edu.om 


$$
\text { المجلة الدولية للدراسات التربوية والنفسية }
$$

International Journal of Educational \& Psychological Studies (EPS)

Journal Homepage: https://www.refaad.com/views/EPSR/Home.aspx

www.refaad.com

ISSN: 2520-4149 (Online) 2520-4130 (Print)

\title{
Entrepreneurial intentions among students of sultan Qaboos university
}

\author{
Salim Saleem Al Ghanboosi \\ Associate Professor, Dept. of Foundations, and Educational Administration, Sultan Qaboos University, Sultanate \\ of Oman \\ ghnbousi@squ.edu.om
}

Aieman Ahmad Al-Omari

Professor, Dept. of Foundations, and Educational Administration, Sultan Qaboos University, Sultanate of Oman a.alomari@squ.edu.om

Received: 18/10/2020 Revised: 24/10/2020 Accepted: 30/10/2020 DOI: https://doi.org/10.31559/EPS2021.9.3.15

\begin{abstract}
:
The purpose of the study is to investigate the entrepreneurial intentions among students of Sultan Qaboos University. Then, to determine if entrepreneurial intentions differ according to students' demographics variables. The study used a questionnaire to collect data as a quantitative methodology. The sample of study included 328 students' that randomly selected. The results of study revealed that entrepreneurial intentions among students at $\mathrm{SQU}$ in general with level of moderate, entrepreneurial intentions of male students higher than female, the entrepreneurial intentions among senior higher than junior, sophomore and freshman. In time of joblessness all institutions of learning from primary to university should involve entrepreneurial education in their curriculum.
\end{abstract}

Keywords: Entrepreneurial Intentions; Students; Sultan Qaboos University; Oman.

\section{Introduction}

Intentionality and forethought are innate human characteristics. Extant psychology literature suggested that intention was the lading predictor of behavior (Bagozzi, Baumgartner, \& Yi, 1989), particularly when behavior is difficult to observe, correlated with uncertain time lag and unusual (Katz \& Gartner, 1988; Krueger \& Brazeal, 1994). Entrepreneurship is one such planned behavior (Bird, 1988; Katz \& Gartner, 1988; Krueger \& Brazeal, 1994). Entrepreneurship is therefore an important process for entrepreneurship as it is the first step in the sequence of acts toward enterprise formation (Bird, 1988). Entrepreneur's purpose is to engage in individual attitudes towards the end result of that particular action and individual self-efficacy (Douglas \& Fitzsimmon, 2008).

Research on the influence of entrepreneurship education on the intentions and behaviors of entrepreneurial individuals in the extant literature is incongruent (Durrant, 2014; Harris, Gibson, \& Taylor, 2008; Matlay, 2006). Fayolle et al. (2006) study in France indicated that entrepreneurial education had impact on students' entrepreneurial intentions, yet insignificant impact on perceived behavioral control. Scholars of entrepreneurship have emphasized the need for a research to assess the impact of entrepreneurship education on intentions and attitudes, due to the lack of clarity regarding causality and unequivocal empirical evidence (Basu \& Virick, 2008; Harris et al., 2008). Also, scholars on entrepreneurship contended that appreciation for forming entrepreneurial intention is imperative to predict entrepreneurial behavior (Lee \& Wong, 2004). The consensus among entrepreneurship researchers is that an individual's intentions are directly related to entrepreneurial activity (Shaver, Gartner, Crosby, Bakalarova, \& Gatewood, 2001).

Entrepreneurship education is rapidly growing as a field of practice, as well as identifying and supporting the intentions to become an entrepreneur are paramount for the 21st century workforce. The construct of

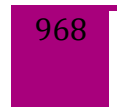

المجلة الدولية للدراسات التربوية والنفسية- المجلد9، العدد3- 2021، ص: 968-976 
entrepreneurial intentions has relevance for development of the field as well as individuals and their contributions to the development of the economy. There is a further need for research in the area of entrepreneurial intentions perspectives in university environments.

Early researchers, Beyers, Johnson, and Stanahan (1987), reasoned that education is a key factor in economic-development-impact entrepreneurship, as the number of entrepreneurs and potential entrepreneurs are influenced by the quality and quantity of education. Advocates of entrepreneurship education pointed out that institutions of higher learning are positioned to provide greater impact, due to accessible knowledge-based resources that are essential to technology advanced enterprises; in turn, these technologies are vital for international competitive economies (McMullan \& Long, 1987). Researchers expressed confidence that entrepreneurship education influences culture and builds entrepreneurial economies (Matlay, 2005a, 2005b; McKeown, Millman, Sursani, Smith, \& Martin, 2006). The significant role of entrepreneurship education in the shaping of attitudes, skills, and behaviors from primary education through higher education, extending to lifelong learners and the overarching effect on those who are socially and economically excluded (Wilson, Vyakarnam, Volkmann, Mariotti, and Rabuzzi, 2009).

Entrepreneurship, defined as the process of starting a business (U.S. Small Business Administration (SBA), 2007). Entrepreneurship is a significant source of wealth creation; more wealth has been created within the past 50 years than any time period. Small Business Administration, entrepreneurship rates were $0.29 \%$ or 290 out of 100,000 adults in the United States created a new business during the period of January 1996 to February 2000 (SBA, 2007).

Between the years 1996-2006, the Kauffman Entrepreneurial Index (KPI) which tracks entrepreneurial activity revealed that there was a subtle shift in demographic and geographic composition of new entrepreneurs across the U.S. The KPI key findings for 2006 reported: (a) approximately 465,000 new businesses were started each month, (b) Asian business owners increased to 32\% from 2005 to 2006, (c) African American entrepreneurial endeavors declined from $24 \%$ to $22 \%$ and (d) the Latino rate increased from $32 \%$ to $33 \%$.

According to the Kauffman Center for Entrepreneurial Leadership (KCEL, 2007), more than 65\% of 14- to 19year-olds are interested in starting a business, compared with about half of the general public. In the 1980's, only 1 to $2 \%$ of graduating MBA's wanted to start out as entrepreneurs, whereas today 10 to $20 \%$ want to be their own bosses (Sinton, 1999). "Control of one's destiny" is the most commonly cited career goal of young entrepreneurs.

In Sultanate of Oman, as a culmination of the symposium on the development of small and medium enterprises held in Saih Al Shamkhat in 2010. His Majesty Sultan Qaboos bin Said established the Al Rafid Fund and issued its regulation in accordance with Royal Decree No. 6/203. The Fund combines the three financing programs: Livelihoods and Rural Women Program, with the aim of empowering young men and women to establish and develop their SMEs. The Fund, which enjoys financial and administrative independence, has a capital of RO 70 million. Al Rafid Fund vision to support Omani youth entrepreneurship towards sustainable growth of the national economy, and mission to provide appropriate funding to ensure the sustainability of SMEs run by Omanis, and attain objectives that developing a culture of entrepreneurship (https://www.alraffd.gov.om/ar/aboutalraffd/Pages/Ourstrategy.aspx).

There are numerous variables impacting individual's decisions to become an entrepreneurship. However, this study is delimited to focus on intended entrepreneur's attitudinal orientation (traits, characteristics and dispositions). A major problem with understanding the entrepreneurial phenomenon is that not enough is known about intentions to become an entrepreneur.

This study objective to: (a) identify intended entrepreneurs among undergraduate students at SQU (b) explore if the entrepreneurial intentions vary according to students' demographic.

\section{Problem Statement and Questions of Study}

Experts, and various educators believe that many types of students have entrepreneurial intentions. Students from various academic majors could be educated in the foundations of entrepreneurial knowledge, skills and attitudes. Recent empirical research in the area of intentions to become an entrepreneur (Segal, Borgia \& Schoenfeld, 2005; Bird, 1988; Franke \& Luethje, 2004) is encouraging.

Extant research on the decisions to become an entrepreneur could be characterized as falling within the domain of planned behavior. There is a strong established relationship between intentions and planned behavior (Ajzen, 1991). The work of Kruger and Carsrud (1993) highlights an intention-based approach that aligns with Ajzen's theory of planned behavior. These intentions-based approaches have spawned theory driven models of how exogenous factors such as demographics, personality traits, characteristics and planned behavior affects entrepreneurial attitudes, activities and behavior. as the population grew faster than the economy could sustain, serious economic challenges have arisen. The growth of Omani population has outstripped the capacity of higher education institutes and the job market. This one created two main challenges for the government- unemployment and provision of opportunities for higher education. These economic and social dilemmas have been key factors in 
pressurizing the government to look at entrepreneurship and self-employment, especially among the young, as key components in tackling these challenges and diversifying the economy (Khan, \& Almoharby, 2007).

This study is significant because it focuses on entrepreneurial intentions. The entrepreneurial intentions focus is important because it provides educators and researchers with data contributing on identifying prospective entrepreneurs. This research study goal was to investigate the entrepreneurial intentions among undergraduate students of Sultan Qaboos University and its relationship with their proactive personality. Then, to determine if entrepreneurial intentions vary according to undergraduate students' demographics.

The following research questions are addressed in this study.

- Research Question 1: What is the level of entrepreneurial intentions among undergraduate students of Sultan Qaboos University?

- Research Question 2: Do the entrepreneurial intentions among undergraduate students of Sultan Qaboos University differ based on their gender, year level (Freshman, Sophomore, Junior, and Senior), gpa (2 to less than 3, 3 to 4), and college (Humanities, Scientific)?

\section{Significance of Study}

Until now, no research in Omani context exists that investigate the entrepreneurial intentions among undergraduate students at SQU. This study is important for several reasons. The entrepreneurial intentions may influence the future of any given organization. The findings of this study will contribute to the knowledge of the institution, revealing strategies that will help to lead the community internal and external.

The study may also suggest areas where additional research in entrepreneurial intentions is needed. It is likewise anticipated that these findings could improve the way educational institutions operate and leaders lead the entrepreneurship.

\section{Delimitations and Limitations of the Study} below.

The results of this study will be considered in view of relevant delimitations and limitations as described

\section{The following are limited generalized statements in this study:}

1. The research study involves undergraduate students in Sultan Qaboos University.

2. The study is limited to undergraduate students in Sultan Qaboos University through Fall semester 2019.

3. The study reflects the level of entrepreneurial intentions among undergraduate students of Sultan Qaboos University.

The following delimitations and generalizations apply to this study:

1. Instrument used in this study to measure the level of entrepreneurial intentions among students at Sultan Qaboos University, may not be representative of other instruments measuring dependent and independent variables of other studies.

2. Data obtained from the study is limited to undergraduate students of Sultan Qaboos University; consequently, outcomes of this study may not be generalized to other universities in the country.

\section{Definitions}

The following terms are used in this research study:

Entrepreneurial intentions: Cognitive undertaking of an individual toward establishing new venture (Bird, 1988; Learned, 1992). Entrepreneurial intention is a psychological construct (commonly used in entrepreneurship research) that refers to the intention to become an entrepreneurial individual or the intentional process to start a business. Intentions have been used to describe a self-prediction to engage in a behavior (Azjen, 1991). In the psychological literature, intentions have proven to be the best predictor of planned behavior, particularly when this behavior is hard to observe (Krueger et al., 2000).

An operational definition of Entrepreneurial intentions in this study means the intention to become an entrepreneurial individual or the intentional process to start a business, as measured by the instrument that prepared by the researchers.

\section{Research Methodology}

\section{Research Design:}

This study used a survey to collect data as a quantitative methodology. 


\section{Population and Sample of study:}

A total of 600 undergraduate students enrolled in four sections of "Ethics of profession" course during the fall semester 2019 served as the sample. The population for the study consisted of undergraduate students at Sultan Qaboos University during the fall semester 2019. The sample of this study included 328 students in undergraduate level were satisfactorily completed the survey, with response rate $54.67 \%$. The final sample included, 157 males with $47.9 \%$, and 171 females with $52.1 \%$. According to academic year; 28, 8.5\% were freshman, 104, 31.7\% were sophomore, 90, 27.4\% were junior, 106, 32.3\% were senior. Regarding to students GPA; $213,64.9 \%$ were " 2 to less than 3", and 115, 35.1\% were "3 to 4". Related to students' college; $163,49.7 \%$ were "humanities', and 165, 50.3\% were "scientific".

\section{Instrumentation:}

Entrepreneurial intention scale. The entrepreneurial intention developed by the researchers, it contains 11 items focused on undergraduate students' entrepreneurial intentions, that aim to capture the intention of an individual to start a business. Participants were asked to specify for each statement whether they agree or disagree with. The students' entrepreneurial intention scale that developed by the researchers, based on different studies, and revisits the efforts of those studies, as (Ajzen, 1991; Krueger \& Carsrud, 1993; Krueger et al., 2000; Von Graevenitz, Harhoff, \& Weber, 2010; Mueller, 2011; Fayolle \& Liñán, 2013; Fayolle \& Gailly, 2015; Sabah, 2016).

\section{Instrument Validity:}

For the purpose of examining the validity of the instruments in this study (face validity evidence) it was presented to six experts in educational administration, research and evaluation and educational measurement. They were asked to check whether the statements in the instrument are clear and properly linked to the study issue. On the basis of the expert comments, several changes to the language of the instrument have been made, with the numbers of instrument items, that 11 items.

\section{Instrument Reliability:}

Regarding the reliability of the instrument in this study, an internal consistency procedure (to estimate the consistency across the items) was used. A pilot study of 25 participants had been conducted. Those participants did not participate in the final study. The values of Cronbach alpha (the internal consistency coefficient) for entrepreneurial intentions Scale were 0.82 .

\section{Collection and Analysis of Data:}

Statistical Package for Social Sciences was used to analyze the data. Means, standard deviations, ANOVA analysis were calculated for the research questions. With regard to the cut points, the response scale of each item that ranged from 1 (strongly disagree) to 5 (strongly agree) determined as follows: $1.00-2.33=$ low, 2.34 to 3.67 $=$ moderate, and 3.68-5.00 = high. The researchers convert the scale range to three levels as the following formula: 5 (highest range of scale) -1 (lowest range of scale) $=4,4 / 3$ (levels) $=1.33$, then added (1.33) to the lowest level $(1)=2.33$, then the low level $=1$ to 2.33 , the moderate level $=2.34-3.67$, and high level $=3.68-5$.

\section{Results and Discussion}

\section{Research Question 1. What is the level of entrepreneurial intentions among undergraduate students of Sultan} Qaboos University?

Means and standard deviations for the level of entrepreneurial intentions among undergraduate students of Sultan Qaboos University calculated as follows: $(M=3.56, S D=0.739)$ in moderate level.

Table (1): Means and standard deviations for the level of entrepreneurial intentions at Sultan Qaboos University among undergraduate students

\begin{tabular}{|c|c|c|c|c|}
\hline \# & Items & Mean & SD & Level \\
\hline 1 & I'm ready to make anything to be an entrepreneur. & 3.86 & 0.886 & High \\
\hline 2 & My professional goal is becoming an entrepreneur. & 3.44 & 1.006 & Moderate \\
\hline 3 & I will make every effort to start and run my own business. & 3.94 & 0.860 & High \\
\hline 4 & I'm determined to create my own company in the future. & 3.64 & 1.066 & Moderate \\
\hline 5 & I have very seriously thought of starting a firm. & 3.36 & 1.121 & Moderate \\
\hline 6 & I have the enterprise intention to start an enterprise someday. & 3.72 & 1.090 & High \\
\hline 7 & I will probably own my own business one day & 4.20 & 0.789 & High \\
\hline 8 & $\begin{array}{l}\text { It is likely that I will personally own a small business in the relatively } \\
\text { near future }\end{array}$ & 3.46 & 1.046 & Moderate \\
\hline 9 & I'm figuring out how to start a business & 3.56 & 1.099 & Moderate \\
\hline 10 & I spend time learning how to start a business & 2.99 & 1.128 & Moderate \\
\hline 11 & I'm saving money to start a business that I have in mind & 2.94 & 1.228 & Moderate \\
\hline Total & & 3.56 & 0.739 & Moderate \\
\hline
\end{tabular}


Table 1 results showed that SQU students are willing to be entrepreneurs in future, as shown by their intentions in items 6, 1, 3 and 7, which range from 3.72, 3.86, 3.94 and 4.2 respectively. In general, the intentions of SQU students to be entrepreneurial were moderate with mean 3.59 and standard deviations of 0.739 . This return to undergraduate's students at SQU that have positive for entrepreneurship after graduating. This result consented with the results of Ibrahim et al (2017) that showed that graduates in Oman have a positive attitude towards entrepreneurship.

Research Question 2. Do the entrepreneurial intentions among undergraduate students of Sultan Qaboos University differ based on their gender, year level (Freshman, Sophomore, Junior, and Senior), gpa (2 to less than 3,3 to 4 ), and college (Humanities, Scientific)?

To answer this question, descriptive statistics includes means and standard deviation were used. Table 2 includes the mean and standard deviation for the level of entrepreneurial intentions among undergraduate students of Sultan Qaboos University differ based on their gender, year, gpa, and college.

Table (2): Means and Standard deviation for the level of entrepreneurial intentions among undergraduate students of Sultan Qaboos University differ based on their gender, year, gpa, and college

\begin{tabular}{|c|c|c|c|c|}
\hline \multirow[t]{2}{*}{ Variables } & \multirow[t]{2}{*}{ Level } & \multicolumn{2}{|c|}{ Total } & \multirow[t]{2}{*}{$\mathrm{N}$} \\
\hline & & $\mathrm{M}$ & SD & \\
\hline \multirow[t]{2}{*}{ Gender } & Male & 3.67 & .078 & 157 \\
\hline & Female & 3.38 & .077 & 171 \\
\hline \multirow[t]{4}{*}{ Year } & Freshman & 3.35 & .158 & 28 \\
\hline & Sophomore & 3.39 & .076 & 104 \\
\hline & Junior & 3.64 & . 096 & 90 \\
\hline & Senior & 3.72 & .090 & 106 \\
\hline \multirow[t]{2}{*}{ GPA } & 2 to less than 3 & 3.61 & .061 & 213 \\
\hline & 3 to 4 & 3.44 & .091 & 115 \\
\hline \multirow[t]{2}{*}{ College } & Humanities & 3.55 & .078 & 163 \\
\hline & Scientific & 3.50 & .077 & 165 \\
\hline
\end{tabular}

To achieve the significant differences in the entrepreneurial intentions among undergraduate students of Sultan Qaboos University differ based on their gender, year, gpa, and college. Four-Way ANOVA analysis were used, the results of ANOVA presented in table 3.

Table (3): Four-Way ANOVA result of the level of entrepreneurial intentions among undergraduate students of Sultan Qaboos University differ based on their gender, year, gpa, and college

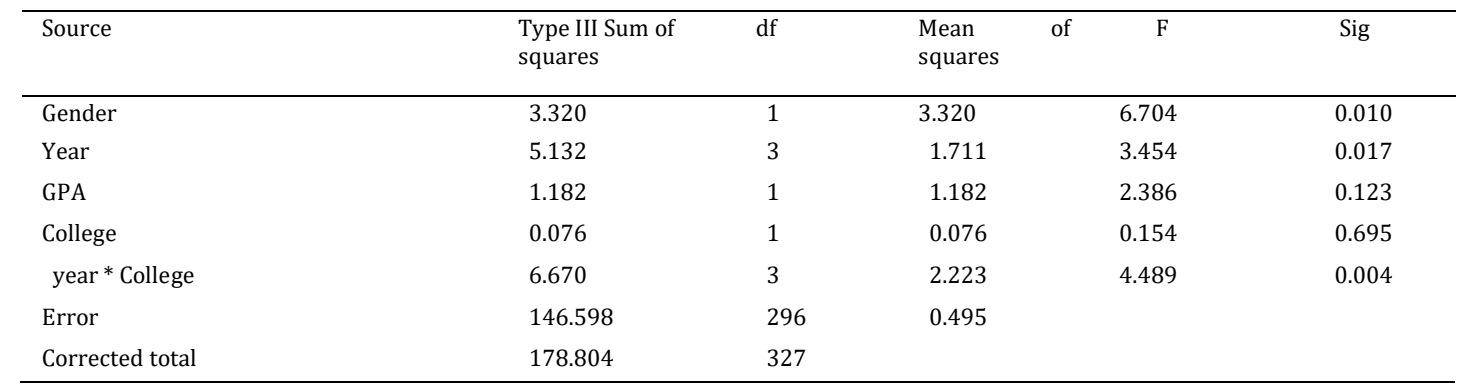

Table 3 shows that no significant differences in entrepreneurial intentions level among undergraduate students of Sultan Qaboos University differ based on their GPA, and college variables. Table 3 shows that there are significant differences in the entrepreneurial intentions among undergraduate students of Sultan Qaboos University according to their gender, year variables, and interaction between year and college.

The significant differences in entrepreneurial intentions among undergraduate students of Sultan Qaboos University based on their gender variable in favor to Male $(M=3.67, S D=.078)$, while female $(M=3.38, S D=.077)$. this result reveals that males are more suspicious than female to get finance resources, as the culture of Omani society males have to take care of their family needs. Many studies found that male generally have stronger entrepreneurial intention than females (Begley et al., 2005, Blanchflower, 2004; Delmar and Davidsson, 2000 this results supported by report published in Spain showed that students in Spain have attitudes towards an entrepreneurs, especially within a higher percentage among males (Guerrero, et al., 2016).therefore, according to theoretical research, the evidence strongly points that an asymmetrical behavior in entrepreneurship between genders roots down to the following reasons. First, that entrepreneurship as a career choice has been argued that currently adjusts better with male, rather than female, traits, especially, attitudinal, behavioral and motivationally (Muntean and Ozkazanc-Pan, 2015).

Many studies found that male generally have stronger entrepreneurial intention than

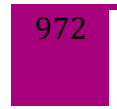

المجلة الدولية للدراسات التربوية والنفسية- المجلد9، العدد3- 2021، ص: 968-976 
females (Blanchflower, 2004; Begley et al., 2005; Delmar and Davidsson, 2000

Many studies found that male generally have stronger entrepreneurial intention than

females (Blanchflower, 2004; Begley et al., 2005; Delmar and Davidsson, 2000

Many studies found that male generally have stronger entrepreneurial intention than

females (Blanchflower, 2004; Begley et al., 2005; Delmar and Davidsson, 2000

Many studies found that male generally have stronger entrepreneurial intention than

females (Blanchflower, 2004; Begley et al., 2005; Delmar and Davidsson, 2000

To achieve the significant differences in the entrepreneurial intentions among undergraduate students of Sultan Qaboos University according to their year variable, post hoc test (Scheffe) were used, the results of Scheffe test presented in table 4.

Table (4): Scheffe result of perceive the entrepreneurial intentions level among undergraduate students of Sultan Qaboos University based on their year variable

\begin{tabular}{lllllll}
\hline Variables & Level & Mean & Freshman & Sophomore & Junior & Senior \\
\hline Year & Freshman & 3.35 & - & .1361 & -.1856 & -.1365 \\
& Sophomore & 3.39 & -.1361 & - & $-.3218^{*}$ & -.2727 \\
& Junior & 3.64 & .1856 & $.3218^{*}$ & - & .0491 \\
& Senior & 3.72 & .1365 & .2727 & -.0491 & - \\
\hline
\end{tabular}

*The mean difference is significant at the .05 level.

Table 4 shows that significant differences in entrepreneurial intentions level among undergraduate students of Sultan Qaboos University based on their year variable between sophomore and junior in favor to junior. This result reveals that SQUs' junior students through their study requirements become more awareness to start their own business, especially in times of economic crisis and joblessness in the Omani government, given that the high level of youth unemployment, youth entrepreneurship has also attracted attention as a mean of promoting employment opportunities. This result was confirmed by Ibrahim, Devesh and Ubiadullah (2017) in study conducted in Oman revealed that graduates in Oman have a positive attitude towards entrepreneurship.

For interaction between "year and college" variables regarding to entrepreneurial intentions level among undergraduate students of Sultan Qaboos University, means and Standard error for interaction were calculated as shown in Table 5.

Table (5): Means and Standard error for interaction between "year * college" variables with regard to entrepreneurial intentions level among undergraduate students of Sultan Qaboos University

\begin{tabular}{llcl}
\hline Year & College & Mean & Std. Error \\
\hline Freshman & Humanities & 3.486 & .226 \\
& scientific & 3.222 & .221 \\
Sophomore & humanities & 3.604 & .109 \\
& scientific & 3.167 & .106 \\
Junior & humanities & 3.552 & .158 \\
& scientific & 3.723 & .108 \\
Senior & humanities & 3.536 & .100 \\
& scientific & 3.894 & .149 \\
\hline
\end{tabular}

Figure (1) shows that students at humanities colleges who are in freshman, and sophomore, have entrepreneurial intentions than students at scientific colleges. While students at scientific colleges in junior and senior years have entrepreneurial intentions higher than students in humanities colleges. These high means of SQUs' students - junior and senior years - are reflecting their potential to become entrepreneurs before their graduate, this potential supported by their graduating projects, which are funded by local companies, most of these projects its part of scientific competitions organize authorize by formal partners. These partners (SQU, 2020) i.e. Petroleum Development Oman, Industrial Innovation Center, Haya Water, Majan Electricity Company, Oman Tel, Occidental Oil \& Gas - Oman, and others). 


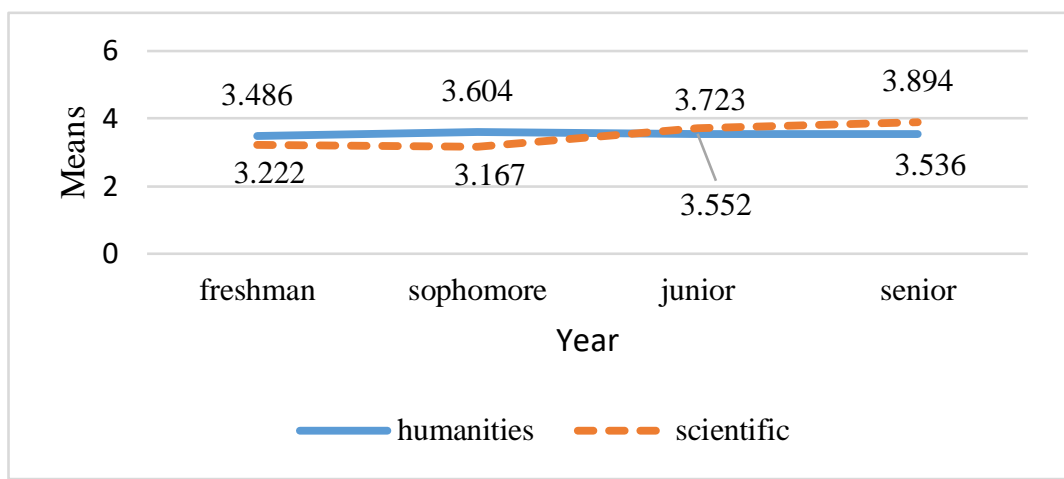

Figure (1): Means of interaction between year*college variables with regard to entrepreneurial intentions level among undergraduate students of Sultan Qaboos University

\section{Conclusions}

Summarizing, it can be concluded that; Globally entrepreneurship education is rapidly growing as a field of practice, as well as identifying and supporting the students' intentions to become an entrepreneur are paramount for the 21st century workforce. The results of this revealed that entrepreneurial intentions among undergraduate's students at SQU in general with level of moderate, intentions of male to be entrepreneurial was higher than female, the entrepreneurial intentions among senior higher than junior, sophomore and freshman. In time of joblessness all institutions of learning from primary to university should include entrepreneurial education in their curriculum. According to Lee et al (2005) education is the key factor that determines entrepreneurial intention, adding that entrepreneurship is not just for students but also for the societies and nations in which it is involved.

This research results confirming the linkage between entrepreneurship and entrepreneurial intentions, and influence of the entrepreneurship education variable on intention. This study concentrated on a nonbusiness discipline that has received little attention, focusing on an under searched, demographic of student sample, their gender, gpa, level of year, and discipline.

\section{Recommendations:}

The results of this study can be used to create opportunities for future research of aspects of entrepreneurship education that influence attitudes and intentions toward entrepreneurship. The influence of entrepreneurship education on entrepreneurial intention has been investigated in prior studies (Bae, Qian, Miao, \& Fiet, 2014; Lange, Marram, Jawahar, Yong, \& Bygrave, 2014; Oosterbeek, 2010).

More research is needed to understand why students' GPA and their colleges did not play such a vital role in entrepreneurial intention. Some authors have found a positive relationship between EE and entrepreneurial intentions (Fayolle \& Gailly, 2015; Kwon \& Arenius, 2010; Mueller, 2011; Von Graevenitz et al., 2010). On the other hand, others have argued that the relationship is non-existent suggesting that the positive effect is due to the self-selection of the participants who voluntarily take the entrepreneurship course (Hamidi, Wennberg, \& Berglund, 2008; Martin, McNally, \& Kay, 2013). Some empirical studies mainly focused on the question of whether or not classes in entrepreneurship have an influence in the decision to become an entrepreneur revealing mixed results (Bae, Qian, Miao, \& Fiet, 2014).

\section{References}

1. Ajzen, I. (1991). The theory of planned behavior. Organizational Behavior and Human Decision Processes, 50: 179-211. https://doi.org/10.1016/0749-5978(91)90020-T.

2. Bae, T. J., Qian, S., Miao, C., \& Fiet, J. O. (2014). The relationship between entrepreneurship education and entrepreneurial intentions: A meta-analytic review. Entrepreneurship Theory and Practice, 38(2): 217-254. https://doi.org/10.1111/etap.12095.

3. Bagozzi, R., Baumgartner, H., \& Yi, Y. (1989). An investigation into the role of intentions as mediators of attitude-behavior relationship. Journal of Economic Psychology, 10(1):35-62, https://doi.org/10.1016/0167-4870(89)90056-1.

4. Basu, A., \& Virick, M. (2008, March). Assessing entrepreneurial intentions amongst students: A comparative study. Paper presented at the 12th Annual Meeting of the National Collegiate Inventors and Innovators Alliance, Dallas, TX.

5. Begley, T.M., Tan, W.L. and Schoch, H. (2005). Politico-economic factors associated with interest in starting a business: $A$ multi-country study. Entrepreneurship: Theory and Practice, 29(1), 33-55. Research Collection Lee Kong Chian School of Business. Available at: https://ink.library.smu.edu.sg/lkcsb_research/2421. 
6. Beyers, W., Johnson, E., \& Stanahan, H. (1987). Education and economic development. Economic Development Commentary, 11(4): 14-17.

a. Blanchflower, D.G. (2004). Self-Employment: More May Not Be Better, NBER working paper No. 10286 [online] http://www.nber.org/papers/w10286 (accessed 20 January 2020).

7. Bird, B. (1988). Implementing entrepreneurial ideas: The case of intentions. Academy of Management Review, 13: 442454. https://doi.org/10.5465/AMR.1988.4306970.

8. Delmar, F. \& Davidsson, P. (2000). Where do they come from? Prevalence and characteristics of nascent entrepreneurs. Entrepreneurship and Regional Development, 12(1): 1-23, https://doi.org/10.1080/089856200283063.

9. Douglas, E. J., \& Fitzsimmons, J. R. (2008). Individual intentions toward entrepreneurship vs. intrapreneurship. Proceedings of the 5th Australian Graduate School of Entrepreneurship International Entrepreneurship Research Exchange (pp. 937-951). Melbourne, Australia: Australian Graduate School of Entrepreneurship.

10. Durrant, D. E. (2014). Entrepreneurial intentions: Making the case for entrepreneurship education. Unpublished Dissertation, Capella University.

11. Fayolle, A., \& Gailly, B. (2015). The impact of entrepreneurship education on entrepreneurial attitudes and intention: Hysteresis and persistence. Journal of Small Business Management, 53(1): 75-93. https://doi.org/10.1111/jsbm.12065.

12. Fayolle, A., Gailly, B., \& Lassas-Clerc, N. (2006). Assessing the impact of entrepreneurship education programmes: A new methodology. Journal of European Industrial Training, 30(9): 701-720. https://doi.org/10.1108/03090590610715022.

13. Fayolle, A., \& Liñán, F. (2013). The future of research on entrepreneurial intentions. Journal of Business Research, 67(5): 663-666, https://doi.org/10.1016/j.jbusres.2013.11.024.

14. Franke, N. \& Luethje, C. (2004). Entrepreneurial intentions of business students: A Benchmark study. International Journal of Innovation and Technology Management, 1(3): 269-288, https://doi.org/10.1142/S0219877004000209.

15. Gelaidan, H. M., \& Abdullateef, A. O. (2017). Entrepreneurial intentions of business students in Malaysia: The role of selfconfidence, educational and relation support. Journal of Small Business and Enterprise Development, 24(1): 54-67. https://doi.org/10.1108/JSBED-06-2016-0078.

16. Guerrero, M., Urbano, D., Ramos, A. R., Ruiz-Navarro, J., Neira, I., \& Fernández-Laviada, A. (2016). Observatorio De Emprendimiento Universitario En España. Edición 2015-2016. Spain: Crue Universidades Españolas-RedEmprendiaCISE.

17. Hamidi, D. Y., Wennberg, K., \& Berglund, H. (2008). Creativity in entrepreneurship education. Journal of Small Business and Enterprise Development, 15(2), 304-320, https://doi.org/10.1108/14626000810871691.

18. Harris, M., Gibson, S., \& Taylor, S. (2008). Examining the impact of small business Institute participation on entrepreneurial attitudes. Journal of Small Business Strategy, 18(2): 57-75.

19. Hockerts, K. (2017). Determinants of social entrepreneurial intentions. Entrepreneurship Theory and Practice, 41(1): 105-130, https://doi.org/10.1111/etap.12171.

20. Ibrahim, O. A. Devish, S. \& Ubadullah, V. (2017). Implication of Attitude of Graduate in Oman Towards Entrepreneurship: An Empirical Study. Journal of Global Research, 7(1): 1-17, https://doi.org/10.1186/s40497-017-0066-2.

21. Katz, J., \& Gartner, W. (1988). Properties of emerging organizations. Academy of Management Review, 13: 429-441, https://doi.org/10.5465/AMR.1988.4306967

22. Kaijun, Y., \& Sholihah, P. I. (2015). A comparative study of the Indonesia and Chinese educative systems concerning the dominant incentives to entrepreneurial spirit (desire for a new venturing) of business school students. Journal of Innovation and Entrepreneurship, 4(1): 1-16. https://doi.org/10.1186/s13731-014-0014-0.

23. Khan, G. M. \& Almoharby, D. (2007). Towards enhancing entrepreneurship development in Oman. Journal of Enterprising Culture, 15(4): 371-392. https://doi.org/10.1142/S0218495807000198.

24. Kauffman Foundation (2007). Retrieved from Kauffman Foundation Web site: http://www.kauffman.org/items.cfm?itemID=704.

25. Krueger, N. F., Jr., \& Brazeal, D. V. (1994). Entrepreneurial potential and potential entrepreneurs. Entrepreneurship Theory \& Practice, 18(3): 91-104, https://doi.org/10.1177/104225879401800307.

26. Krueger, N. F., Reilly, M. D., \& Carsrud, A. L. (2000). Competing models of entrepreneurial intentions. Journal of Business Venturing, 15(5/6): 411-432, https://doi.org/10.1016/S0883-9026(98)00033-0.

27. Krueger, N. F., Jr., \& Carsrud, A. L. (1993). Entrepreneurial intentions: Applying the theory of planned behaviour. Entrepreneurship \& Regional Development, 5: 315-330, https://doi.org/10.1080/08985629300000020

28. Kwon, S. W., \& Arenius, P. (2010). Nations of entrepreneurs: A social capital perspective. Journal of Business Venturing 25(3): 315-330, https://doi.org/10.1016/j.jbusvent.2008.10.008. 
29. Lange, J.E., Marram, E.P., Jawahar, A.S., Yong, W. \& Bygrave, W.D. (2014). Does an Entrepreneurship Education Have Lasting Value: A Study of Careers of 3775 Alumni. Journal of Business and Entrepreneurship, 25(2): 1-31.

30. Learned, K. E. (1992). What happened before the organization? A model of organization formation. Entrepreneurship Theory and Practice, 17(1): 39-48, https://doi.org/10.1177/104225879201700105.

31. Lee, S. M. Chang, D. \& Lim, S. M. (2005). Impact of entrepreneurship Education: A Comparative Study of the U.S. and Korea. The International entrepreneurship and Management Journal, 1: 27-43, https://doi.org/10.1007/s11365-005-6674-2.

32. Lee, S. H., \& Wong, P. K. (2004). An exploratory study of technopreneurial intentions: A career anchor perspective. Journal of Business Venturing, 19(1): 7-28, doi:10.1016/S0883-9026(02)00112-X.

33. Maes, J., Leroy, H., \& Sels, L. (2014). Gender differences in entrepreneurial intentions: a TPB multi-group analysis at factor and indicator level. European Management Journal, 32(5): 784-794, https://doi.org/10.1016/j.emj.2014.01.001.

34. Martin, B. C., McNally, J. J., \& Kay, M. J. (2013). Examining the formation of human capital in entrepreneurship: A metaanalysis of entrepreneurship education outcomes. Journal of Business Venturing, 28(2): 211-224, https://doi.org/10.1016/j.jbusvent.2012.03.002.

35. Matlay, H. (2005a). Entrepreneurship education in UK business schools: Conceptual, contextual and policy considerations. Journal of Small Business and Enterprise Development, 12(4): 627-43, https://doi.org/10.1108/14626000510628270

36. Matlay, H. (2005b). Researching entrepreneurship and education, Part 1: What is entrepreneurship and does it matter? Education and Training, 47(8/9): 665-677, https://doi.org/10.1108/00400910510633198.

37. Matlay, H. (2006). Researching entrepreneurship and education: Part 2: What is entrepreneurship and does it matter? Education and Training, 48(8/9): 704-718, https://doi.org/10.1108/00400910610710119.

38. McKeown, J., Millman, C., Sursani, S. R., Smith, K., \& Martin, L. M. (2006). Graduate entrepreneurship education in the United Kingdom. Education and Training, 48(8/9): 597-613, https://doi.org/10.1108/00400910610710038.

39. McMullan, W. E., \& Long, W. (1987). Entrepreneurship educations in the nineties. Journal of Business Venturing, 2(3): 261-275, https://doi.org/10.1016/0883-9026(87)90013-9.

40. Mueller, S. (2011). Increasing entrepreneurial intention: Effective entrepreneurship course characteristics. International Journal of Entrepreneurship and Small Business, 13(1): 55-74, https://doi.org/10.1504/IJESB.2011.040416.

41. Muntean, S. C., and Ozkazanc-Pan, B. (2015). A Gender integrative conceptualization of entrepreneurship. New England Journal of Entrepreneurship, 18(1): 27-40, https://doi.org/10.1108/NEJE-18-01-2015-B002.

42. Oosterbeek, H., van Praag, M., \& Ijsselstein, A. (2010). The impact of entrepreneurship education on entrepreneurship skills and motivation. European Economic Review, 54(2010): 442-454, https://doi.org/10.1016/j.euroecorev.2009.08.002.

43. Sabah, S. (2016). Entrepreneurial Intention: Theory of planned behavior and the moderation effect of start-up experience. Entrepreneurship - Practice-Oriented Perspectives, Mario Franco, IntechOpen, https://doi.org/10.5772/65640. Available from: https://www.intechopen.com/books/entrepreneurship-practice-oriented-perspectives/entrepreneurialintention-theory-of-planned-behaviour-and-the-moderation-effect-of-start-up-experien

44. Shaver, K. G., Gartner, W. B., Crosby, E., Bakalarova, K., \& Gatewood, E. J. (2001). Attributions about entrepreneurship: A framework and process for analyzing reasons for starting a business. Entrepreneurship Theory \& Practice, 26(2): 5-28. https://doi.org/10.1177/104225870102600201.

45. Segal, G., Borgia, D., \& Schoenfeld, J. (2005). The motivations to become and entrepreneur. International Journal of Entrepreneurial Behavior and Research, 11(1):42-57, https://doi.org/10.1108/13552550510580834.

46. SQU (2020). List of Companies Linked to Research and Innovation Activities. Retreated from: https://www.squ.edu.om/engineering.

47. U. S. Small Business Administration (2007). Retrieved from U.S. Small Business Administration Web site: http://sba.gov/index.html, https://www.alraffd.gov.om/ar/about-alraffd/Pages/Ourstrategy.aspx

48. Wilson, K E., Vyakarnam, S., Volkmann, C., Mariotti, S., \& Rabuzzi, D. (2009). Educating the Next Wave of Entrepreneurs: Unlocking Entrepreneurial Capabilities to Meet the Global Challenges of the 21st Century (April 29, 2009). World Economic Forum: A Report of the Global Education Initiative, April 2009, Available at SSRN: https://ssrn.com/abstract=1396704 or http://dx.doi.org/10.2139/ssrn.1396704

49. Von Graevenitz, G., Harhoff, D., \& Weber, R. (2010). The effects of entrepreneurship education. Journal of Economic Behavior and Organization, 76(1): 90-112, https://doi.org/10.1016.j.jebo.2010.02.015.

50. Wang, S., Yueh, H., \& Wen, P. (2019). How the new type of entrepreneurship education complements the traditional one in developing entrepreneurial competencies and intention? Front Psychol, 10, https://doi.org/10.3389/fpsyg.2019.02048. 